\title{
WhatsApp Group Increase Antenatal Visit
}

\author{
Sari Ardiyanti ${ }^{1}$, Mufdlilah ${ }^{2}$, Wiwik Kusumawati ${ }^{3}$, Winny Setyo Nugroho ${ }^{4}$ \\ ${ }^{1,2}$ Master of Midwifery Program, Faculty of Health Sciences, 'Aisyiyah University of Yogyakarta \\ ${ }^{3,4}$ Medical Faculty, Muhammadiyah University of Yogyakarta \\ 19ardiyantisari009@gmail.com*, ${ }^{2}$ mufdlilah.stikes@gmail.com, ${ }^{3}$ wiwik_fk_umy@yahoo.com.sg, \\ ${ }^{4}$ wsetyonugroho@gmail.com \\ * corresponding author \\ Submission date: 10 Juli 2018, Receipt date: 10 Oktober 2019, Publication date: 1 Juli 2020
}

\begin{abstract}
The maternal mortality rate in Indonesia reached 305 / 100,000 live births; it is associated with a lower ANC visit. The promotion of health has a positive effect on increasing the ANC, which can be done with WhatsApp group (WAG). This study aimed on improving knowledge through health promotion with WhatsApp group at the health centres of Yogyakarta. This study was Quasi-experimental design using pre-test posttest non-equivalent control group design. Samples numbered 62; the sampling technique used consecutive sampling. The samples were divided into two groups namely intervention and control groups. The survey result showed that the highest frequency distribution was from the group that receivedon schedule health promotion as many as $17(27,4)$ respondents, and those were not on schedule $15(24,2 \%)$ of respondents. The interventionsgroup with 36.68 Mean Rank was higher than the control group 26.32. In addition, the Z-count value obtained by -2.365 and p-value of 0.018 meaning that the correlation was significant. In, conclusion, the group that received the intervention had higher rate of ante natal visit compared to the control group, and there is a significant difference between the visits in the intervention group and the control.
\end{abstract}

Keywords: health promotion, whatsapp group

\section{INTRODUCTION}

Maternal Mortality Rate (MMR) is an indicator of a nation's welfare (Budiman, Juhaeriah, \& Gina, 2010), Number of MMR is still quite high. The world MMR still reached 289,000 incidences (Agus\&Horiuchi, 2012). While in Indonesia, it reached 305 among 100,000 live births (KemenKesRI, 2015), and in the municipality of Yogyakarta the maternal mortality reached 125 among 100,000 live births (DinKesKotaYogyakarta, 2015). The high rate of maternal mortality could be prevented by the improvements in quality of Antenatal Care (ANC) visit as many as four times during pregnancy (Carroli, Rooney, Villar, 2001), (Campbell, Graham, \& group, 2006).

By doing regular antenatal visits, it can reduce the morbidity and mortality of mothers and new-borns, and can improve the health of both mother and baby (Carroli et al., 2001), (Campbell et al., 2006). At the time of prenatal care, pregnant women will get a variety of services such as health promotion and preventive health care that become very important thing in identifying risk factors that occur during pregnancy (Stine Lund et al., 2014). The role ofthe midwife is needed in increasing the coverage of ANC visits, in providing counselling of antenatal visits (Medhanyie, Spigt, Dinant, \& Blanco, 2012; Sharma et al., 2016). However, many pregnant women still do not want 
to visit antenatal care, especially in developing countries (McNabb et al., 2015). Data of preliminary study conducted in Yogyakarta municipality showed that there were two health centres with low coverage antenatal visits Primary Health Centers of Mergangsan and Danurejan 2 (DinKesKotaYogyakarta, 2017). An effective way to increase the rate of ANC through the promotion of health, either directly orindirectly, using the right media (Sharma et al., 2016).

Nowadays, the use of mobile phones is increasing, thus it can encourage health facilities to start utilizing $\mathrm{m}$-Health in the implementation of health services ((Lori, Munro, Boyd, \&Andreatta, 2012; Stine Lund et al., 2014)). M-Health is considered to strengthen the health system (Howitt et al., 2012). By utilizing mobile technologies (smartphones) which is a form of m-Health application, it can be used as a good medium for conveying health promotion messages for individuals or groups (Free et al., 2013).

Most pregnant women have applications in smartphones that can be used to support health behaviour. One of which is the use of WhatsApp app as a means for health promotion (Sunday O Oyeyemi\& Wynn, 2015; Ellanti, Moriarty, Coughlan, \& McCarthy, 2017). WhatsApp has many advantages, which can be used for private communication, groups, or so-called WhatsAppGroup (WAG) (Ellanti et al., 2017). WhatsApp can send picture, video, voice, and video telephonemessages, moreover it is very easy to operate (Montag et al., 2015). With WhatsApp group, members in the group can communicate together and make it easier to exchange information (Ellanti et al., 2017). The purpose of this research was to improve antenatal visit through health promotion interventions with WhatsApp media group.

\section{RESEARCH METHODS}

This study used a quasi-experimental design with non-equivalent control group design. The study was conducted in health centres of Mergangsan and Danurejan 2, since July until August 2017.

Respondents in this study were pregnant women within the scope of health centres of Mergangsan and Danurejan 2 Yogyakarta, with a sample of 62 pregnant women. Respondents were divided into 2 groups; 31 pregnant women from primary health centre of Mergangsanand 31 pregnant women in the control group from the primary health centre of Danurejan 2. The respondents got health care when the mother visited the health workers.

The inclusion criteria were pregnant women who had a WhatsApp application, were able to operate WhatsApp well, and were willing to become respondents. Theinstrument of this study used a questionnaire which tested the validity and reliability of the health centres in the municipality of Yogyakarta. The experimental group was given an intervention in the form of health promotion using the media WhatsApp group for 3 times within two weeks. The provision of material had been adjusted to the needs of pregnant women, namely trimester IIpregnant women, and the material provided in this study had been reviewed by an expert of the field. Before starting a promotional activity, pregnant women who were absent from the group were expected to actively ask questions during the health promotion. Health promotion material using WhatsApp group was given in the form of a video made by the researcher. This material was uploaded into the WhatsApp group. After that, the researcher uploaded a video about the needs of the mother during pregnancy. 
The material covered warning signs during pregnancy and activities that should not be done by the mothers during pregnancy. If all pregnant women had downloaded the video, the researcher gave an explanation of the video by using the text in accordance with the material given in the video. After two weeks of intervention, pregnant women were evaluated to check if they understood the material. Then one month later, they were evaluated to see if there was an increase in visits in pregnant women who had received health promotion by checking the status of pregnant mothers' re-visits at the Mergangsan Primary Health Centre.

The control group only got antenatal care by health workers at the health centres. The same evaluation was given to the control group to check for an increase in antenatal care visits after one month by seeing the re-visit registers at the Danurejan 2primary health centre.

This research had been conducted by the permission of ethics committee of the Universitas 'Aisyiyah Yogyakarta No: 15 / KEP-UNISA / VII / 2017. Then, inform consent was signed by the respondents who were willing to participate in the study and were also signed by the witnesses.

To provide an overview of the increasing number of ANC visits, a frequency distribution was calculated for groups of pregnant women who had received health promotion and pregnant women who did not receive health promotion. To find out the difference between pre-test and post-test, the group that received health promotion and groups that did not receive health promotion got information about basic needs for pregnant women, warning signs of pregnancy and things that were not allowed to the mothers during pregnancy. The researchers tested the normality of the data. Then, the results were obtained that the data were not normally distributed, so the difference between pre-test and post-test was done using the mann-whitney test.

\section{RESULTS AND DISCUSSION}

Distribution of visits frequency before and after being given health promotion using the media WAG on intervention group and control could be seen in the following table.

Table 1. Frequency distribution of ANC visits

\begin{tabular}{lcccc}
\hline \multirow{2}{*}{ Visit } & \multicolumn{2}{c}{ Intervention } & \multicolumn{3}{c}{ Control } \\
\cline { 2 - 5 } & $\mathbf{n}$ & $\mathbf{\%}$ & $\mathbf{n}$ & $\mathbf{\%}$ \\
\hline Not Visit & 5 & 8,1 & 7 & 11,3 \\
Not On Schedule & 9 & 14,5 & 15 & 24,2 \\
On schedule & 17 & 27,4 & 9 & 14,5 \\
\hline
\end{tabular}

Table 1 showed the antenatal visit after the health promotion at antenatal classes with WAG media. The intervention group obtained that the highest rate was on schedule as many as 17 respondents (27.4) and in the control group. The highest number was not in accordance with the schedule with as many as 15 respondents (24.2). The differenceANC Visits between the group with Health promotion at antenatal classes with WAG and Media and Control Group that did not Get Intervention could be seen in the following table.

Table 2: Differences ANC visits

\begin{tabular}{lccc}
\hline \multicolumn{1}{c}{ Group } & Mean Rank & Z-count & Asym p.Sig (2-tailed) \\
\hline $\begin{array}{l}\text { Intervent } \\
\text { ion }\end{array}$ & 36,68 & $-2,365$ & 0,018 \\
& & &
\end{tabular}


The results of the intervention group obtained mean rank (36.68) that was higher than the control group(26.32) with $Z$-count in the intervention and control of $(\mathrm{z}=-2.365)$ and obtained the $\mathrm{p}$-value of $(\mathrm{p}=0.018)$ i.e., $\mathrm{p}<0.05$ (Table 2)

The survey results revealed that an increase in ANC visits was in the intervention group. It could be concluded that after being treated by the health promotion through WAG media, the visit rate of pregnant women increased. In a study conducted by Sunday OluwafemiOyeyemi\& Wynn (2014) suggested that antenatal visits in the intervention group throughcell phones were significantly higher compared to the control group. This showed that most pregnant women after getting a health promotion intervention by WAG media wanted to do visit according to the time set by the health personnel at the time of the examination.

Mann-Whitney test results explained that there was a significant difference between the group that received health promotion and the group that did not receive the health promotion. The results of this study supported by research conducted by S Lund et al. (2012) stating that phone interventions improved antenatal care attendance, and there was atendency to improve the quality of healthcare as a form of preventiveactivity for the mother's health condition.

According to Notoatmodjo (2007), it is stated that behaviour is "a result of the relationship between stimulus and response". In this case, stimulation conducted by researchers was by giving health promotion activities through the medium of WAG, and the resulting action was a change in behaviorrecommended by health professionalsin the form of antenatalvisits.

The provision of health information using WAG media could increase knowledge about health during pregnancy. Furthermore, a good knowledge would lead to awareness, and ultimately it would cause a pregnant woman to behave in accordance with the knowledge which was in the form of ANC visits. To boost the quality of antenatal care, the World Health Organization (WHO) recommended at least four antenatal care visits for pregnancies without complications with the first visit started before 16 weeks of pregnancy (Stine Lund et al., 2014).

The research conducted by Khoramabadi et al. (2016) stated that behaviour was a response to stimulus in real form or practice that could easily be observed by others. The process of behaviour change that occurred in pregnant women included awareness, feelings of interest, evaluation, try and adaption in accordance with the awareness and attitudes of pregnant women. If the behaviour of pregnant women in conducting antenatal visits was based on awareness and feelings of interest to conduct antenatal visits, these behaviours could occur continuously. In different ways, if the behaviour was not based on awareness and feelings of interest, pregnant women tended not to want to do antenatal visits. One other study conducted by Sunday OluwafemiOyeyemi\& Wynn (2014) argued that the provision of health information through the medium of mobile phones could increase visits of pregnant women to health care and reduce the occurrence of maternal deaths.

\section{CONCLUSION}

There was an increase in ante natal visits to pregnant women who received health promotion, and there was a difference between the groups that received health promotion and those who did not receive health promotion. The weakness in this study 
was the dependent variable that only found out the increase in visits. Hence, the researcher should explore further about the increase in visits due to an increase in knowledge and behaviour of pregnant women after health promotion.

It is suggested that further researches add more dependent variables in the form of knowledge and behaviour, as well as add characteristics of research respondents.

\section{REFERENCES}

Agus, Y., \& Horiuchi, S. (2012). Factors influencing the use of antenatal care in rural West Sumatra, Indonesia. BMC pregnancy and childbirth, 12(1), 9.

Budiman, R. A., Juhaeriah, J., \& Gina, H. (2010). Faktoribu yang berhubungandenganberatbadanbayilahir di Puskesmas Garuda Tahun 2010. Jurnal Kesehatan Kartika, 1, 1-12.

Campbell, O. M., Graham, W. J., \& group, L. M. S. S. s. (2006). Strategies for reducing maternal mortality: getting on with what works. The Lancet, 368(9543), 12841299.

Carroli, G., Rooney, C., \&Villar, J. (2001). How effective is antenatal care in preventing maternal mortality and serious morbidity? An overview of the evidence. Paediatric and perinatal Epidemiology, 15(s1), 1-42.

DinKesKotaYogyakarta. (2015). Profil Kesehatan Kota Yogyakarta. Retrieved from Yogyakarta

DinKes Kota Yogyakarta. (2017). Profil Kesehatan Kota Yogyakarta. Retrieved from Yogyakarta:

Ellanti, P., Moriarty, A., Coughlan, F., \& McCarthy, T. (2017). The use of Whatsapp smartphone messaging improves communication efficiency within an orthopaedic surgery team. Cureus, 9(2).

Free, C., Phillips, G., Galli, L., Watson, L., Felix, L., Edwards, P. Haines, A. (2013). The effectiveness of mobile-health technology-based health behaviour change or disease management interventions for health care consumers: a stematic review. PLoS medicine, 10(1), e1001362.

Howitt, P., Darzi, A., Yang, G.-Z., Ashrafian, H., Atun, R., Barlow, J. Conteh, L. (2012). Technologies for global health. The Lancet, 380(9840), 507-535.

KemenKesRI. (2015). Kesehatan dalam kerangka Sustainable Development Goals (SDGs). Retrieved from Jakarta:

Khoramabadi, M., Dolatian, M., Hajian, S., Zamanian, M., Taheripanah, R., Sheikhan, Z., Seyedi-Moghadam, A. (2016). Effects of education based on health belief model on dietary behaviors of Iranian pregnant women. Global journal of health science, 8(2), 230.

Lori, J. R., Munro, M. L., Boyd, C. J., \&Andreatta, P. (2012). Cell phones to collect pregnancy data from remote areas in Liberia. Journal of NursingScholarship, 44(3), 294-301.

Lund, S., Hemed, M., Nielsen, B. B., Said, A., Said, K., Makungu, M., \&Rasch, V. (2012). Mobile phones as a health communication tool to improve skilled attendance at delivery in Zanzibar: a cluster randomised controlled trial. BJOG: An International Journal of Obstetrics \& Gynaecology, 119(10), 12561264. 
Lund, S., Nielsen, B. B., Hemed, M., Boas, I. M., Said, A., Said, K., . . .Rasch, V. (2014). Mobile phones improve antenatal care attendance in Zanzibar: a cluster randomized controlled trial. BMC pregnancy and childbirth, 14(1), 29.

McNabb, M., Chukwu, E., Ojo, O., Shekhar, N., Gill, C. J., Salami, H., \&Jega, F. (2015). Assessment of the quality of antenatal care services provided by health workers using a mobile phone decision support application in northern Nigeria: a pre/post-intervention study. PLOS one, 10(5), e0123940.

Medhanyie, A., Spigt, M., Dinant, G., \& Blanco, R. (2012). Knowledge and performance of the Ethiopian health extension workers on antenatal and delivery care: a cross-sectional study. Human resources for health, 10(1), 44.

Montag, C., Kannen, C., Lachmann, B., Sariyska, R., Duke, É., Reuter, M., \&Markowetz, A. (2015). The importance of analogue zeitgebers to reduce digital addictive tendencies in the 21 st century. Addictive Behaviors Reports, 2 , 23-27.

Notoatmodjo, S. (2007). Promosi kesehatan dan ilmu perilaku. Jakarta: Rineka Cipta, 20.

Oyeyemi, S. O., \& Wynn, R. (2014). Giving cell phones to pregnant women and improving services may increase primary health facility utilization: a casecontrol study of a Nigerian project. Reproductive health, 11(1), 8.

Oyeyemi, S. O., \& Wynn, R. (2015). The use of cell phones and radio communication systems to reduce delays in getting help for pregnant women in low-and middle-income countries: a scoping review. Global health action, 8.

Sharma, S., Van Teijlingen, E., Belizán, J. M., Hundley, V., Simkhada, P., \&Sicuri, E. (2016). Measuring What Works: An impact evaluation ofwomen's groups on maternal health uptake in rural Nepal. PloS one, 11(5), e0155144. 